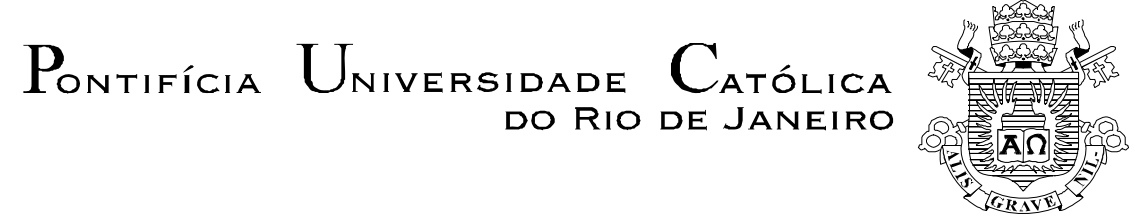

Anna Lee Rosa de Freitas

Umas histórias outras de João Goulart: a construção de um personagem no teatro da política brasileira

Dissertação de Mestrado

Dissertação apresentada como requisito parcial para obtenção do grau de Mestre pelo Programa de Pósgraduação em Letras do Departamento de Letras da PUC-Rio.

Orientadora: Profa. Marília Rothier Cardoso

Rio de Janeiro

Março de 2007 


\section{Umas histórias outras de João Goulart: a construção de um personagem no teatro da política brasileira}

Dissertação apresentada como requisito parcial para obtenção do grau de Mestre pelo programa de PósGraduação em Letras do Departamento de Letras do Centro de Teologia e Ciências Humanas da PUC-Rio. Aprovada pela Comissão Examinadora abaixo assinada.

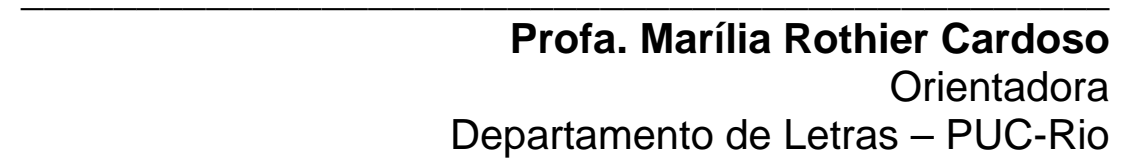

Profa. Ana Paula Veiga Kiffer Departamento de Letras - PUC-Rio

Profa. Célia Maria Leite Costa Fundação Getúlio Vargas
Prof. Paulo Fernando Carneiro de Andrade Coordenador Setorial do Centro de Teologia e Ciências Humanas - PUC-Rio

Rio de Janeiro, de de 
Todos os direitos reservados. É proibida a reprodução total ou parcial do trabalho sem autorização da universidade, da autora e da orientadora.

\section{Anna Lee Rosa de Freitas}

Jornalista, escritora, doutoranda em Estudos da Literatura pela PUC/Rio. Tem livros publicados pela Editora Objetiva e séries infanto-juvenis pelas editoras Moderna e Record. Ganhou o Prêmio Jabuti/2004 - categoria Reportagem e Biografia por $O$ Beijo da Morte. Trabalhou no jornal Folha de S. Paulo, entre outras empresas de comunicação.

Ficha Catalográfica

Freitas, Anna Lee Rosa de

Umas histórias outras de João Goulart: a construção de um personagem no teatro da política brasileira / Anna Lee Rosa de Freitas ; orientadora: Marília Rothier Cardoso. -2007.

102 f. ; $30 \mathrm{~cm}$

Dissertação (Mestrado em Letras) - Pontifícia Universidade Católica do Rio de Janeiro, Rio de Janeiro, 2007.

Inclui bibliografia

1. Letras - Teses. 2. Cinema e literatura. 3. Política. 4. História. 5. Jornalismo. 6. Teatro. 7. Correspondência. I. Cardoso, Marília Rothier. II. Pontifícia Universidade Católica do Rio de Janeiro. Departamento de Letras. III. Título. 
Para meus pais, Liana (in memoriam) e Edgard, meus irmãos, Maria Lúcia (in memoriam), Elizabeth, Edgard e Nayla, e meu afilhado, Felipe, com todo o meu amor. 


\section{Agradecimentos}

À minha orientadora, Marília Rothier Cardoso, por ter me ensinado o caminho do Tempo Glauber e, acima de tudo, por toda e tanta generosidade.

À Ana Paula Kiffer, portadora das “idéias cuja força viva é idêntica à da fome”.

À Célia Maria Leite Costa, pela gentileza de participar dessa banca de Mestrado.

À Pina Coco, pela atenção carinhosa que sempre me dispensou.

Á família de João Goulart, especialmente, à Denize e ao João Vicente, pela confiança.

Ao Tempo Glauber, especialmente, à Dona Lúcia e à Ana Lúcia, sempre acolhedoras.

Ao Cony, eterna referência.

À Luciana Gattass, um encontro para a vida inteira.

À Myrtes Folegatti, companheira de alegrias e inquietações.

À Tânia Dias, por ter me mostrado a direção.

À Francisca Ferreira de Oliveira, a querida Chiquinha, dona de todas as soluções.

Ao querido amigo Sérgio Barcellos, por ter me ajudado nos primeiros passos.

À Capes e à PUC - Rio, pelos auxílios concedidos, sem os quais este trabalho não poderia ter sido realizado. 


\section{Resumo}

Freitas, Anna Lee Rosa de; Cardoso, Marília Rothier (Orientadora). Umas histórias outras de João Goulart: a construção de um personagem no teatro da política brasileira. Rio de Janeiro, 2007. 102p. Dissertação de Mestrado - Departamento de Letras, Pontifícia Universidade Católica do Rio de Janeiro.

Umas histórias outras de João Goulart: a construção de um personagem no teatro da política brasileira é um ensaio - em que narração e descrição foram mescladas com a escrita argumentativa - sobre a trajetória enigmática do ex-presidente João Goulart, do Golpe de 64 até sua morte no exílio, em 1976. O palco político onde Jango atuou serve de objeto a esta dissertação não para investigar sua dimensão histórica, mas com o propósito de revelar e analisar criticamente a trama de discursos que tentaram desvendar essa trajetória, os quais estão instalados em estatutos diferentes. São eles: o fabulista, utilizado pelo cineasta Glauber Rocha, o memorialista, pelo antropólogo Darcy Ribeiro, o epistolar, pelo próprio Jango, o oficial, pelo governo da Ditadura Militar, o informativo, pela imprensa, e, ainda, o ficcional/jornalístico, pela autora da dissertação, que, ao incluir um texto com sua própria assinatura, no corpus textual da pesquisa, pretendeu evidenciar a orientação auto-identificadora e auto-reflexiva da mesma. A perspectiva teórica com a qual se trabalhou foi a de que os relatos do governo e da imprensa, enquanto propostas de verdade conclusiva, são apenas reativos e não correspondem ao poder que exerceram, na circunstância de sua divulgação. De acordo com essa visão, a força especulativa só existe na atividade fabuladora, isto é, só a arte e os discursos claramente interessados é que ativam os signos do passado, tornando-os passíveis de desvendamento, ao mesmo tempo em que se prestam a reflexões que servem para entender o presente.

\section{Palavras-chave}

Cinema e literatura; política; história; jornalismo; teatro; correspondência. 


\section{Abstract}

Freitas, Anna Lee Rosa de; Cardoso, Marília Rothier (Advisor). João Goulart's Other Histories: Character Development on Brazil's Political Stage. Rio de Janeiro, 2007. 102p. MSc. Dissertation Departamento de Letras, Pontifícia Universidade Católica do Rio de Janeiro.

\section{João Goulart's Other Histories: Character Development on Brazil's Political}

Stage is an essay - and as such its style is a combination of narration, description, and argumentative or academic prose - which chronicles the path of Brazilian former president João Goulart starting the 1964 coup until his death in exile in 1976. Jango's political setting, as well as the role he plays in it, serves here not as a means of assessing his historical standing, but rather as an object whose purpose is to unveil and critically scrutinize the discourse networks and webs elicited by the former president's political path. These discursive webs appear in a wide variety of categories: there is the storyteller's point of view as seen in the works of filmmaker Glauber Rocha; the anthropologist Darcy Ribeiro's memorialist take; Jango's own epistolary writings; the official version supported by the members of the dictatorial regime; the documental or journalistic disseminated by the media. Finally, in addition to these categories is the fictional/journalistic style adopted by the author of this dissertation as she opts to include an essay bearing her own signature into the corpus of her research. Her intent at doing so: locating and acknowledging her awareness of her stance vis a vis the subject at hand. The present research operates under one theoretical assumption: that official documents and press materials, far from being actual conclusive facts, are mainly reactive in nature. In other words, over the years they have lost their claim to truth. Subscribing to these views, this essay contends that speculation into the past is only achievable if combined with the ability to generate narratives, be these fictional or not. Only imbued with self-reflexive discourse and only within the sphere of art would one be able to activate signs of the past - thus rendering them not only intelligible but capable of eliciting reflection and of offering clues to understanding the present.

\section{Keywords}

Film and Literature; politics; history; journalism; theatre; epitolary writing. 


\section{Sumário}

$\begin{array}{ll}\text { O palco de Jango - Reflexões introdutórias } & 10\end{array}$

1. Jango e seus espectros - Uma ficção de Glauber Rocha 26

2. Glauber e Jango: atração e repulsa - As implicações de uma herança 44

3. Jango, Glauber e Darcy: A correspondência como espaço de questões políticas e afetivas

4. Jango: personagem nos jornais e nos documentos da Ditadura Militar

5. Uma história da desmedida entrega a João Goulart - meu objeto de reportagem 


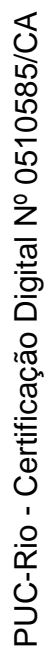

Se cortadas, essas palavras sangram; são dotadas de vascularidade, de vida.

Emerson, sobre os Essais de Montaigne 